\title{
Çocuk Yoğun Bakım Ünitesinde Takip Edilen Zehirlenme Olgularının Demografik, Epidemiyolojik ve Klinik Özelliklerinin Geriye Dönük Değerlendirilmesi
}

\author{
Retrospective Analysis of Demographic, Epidemiologic, and Clinical Characteristics of \\ Poisoning Cases Followed in Pediatric Intensive Care Unit
}

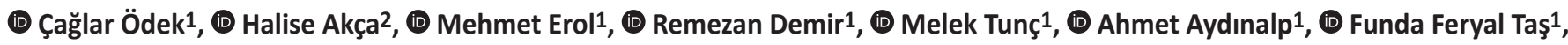 \\ (D) Serhat Samancl 3
}

${ }_{1}^{1}$ Diyarbakır Çocuk Hastalıkları Hastanesi, Çocuk Yoğun Bakım Ünitesi, Diyarbakır, Türkiye

2 Diyarbakır Çocuk Hastalıkları Hastanesi, Çocuk Acil Servisi Kliniği, Diyarbakır, Türkiye

${ }^{3}$ Diyarbakır Çocuk Hastalıkları Hastanesi, Çocuk Sağlığı ve Hastalıkları Kliniği, Diyarbakır, Türkiye

\section{Öz}

Giriş: Bu çalışmanın amacı çocuk yoğun bakım ünitesi (ÇYBÜ)'ne yatarak tedavi gören zehirlenme olgularının demografik, epidemiyolojik ve klinik özelliklerinin değerlendirilmesidir.

Yöntemler: ÇYBÜ'de 1 Ocak 2015 ve 30 Haziran 2016 tarihleri arasında yatarak tedavi gören zehirlenme olguları geriye dönük olarak değerlendirildi.

Bulgular: Çalışmaya 92 olgu dahil edildi. Ortalama yaş 63,65 \pm 59 , 1 ay olup, olguların \%73,9'unu 5 yaş ve altındaki çocuklar oluşturmaktaydı. Olguların \%55,4'ü erkekti. Zehirlenmelerin $\% 82,6$ 'sı kaza sonucu, \%14,1'i ise özkıyım amaçlı meydana gelmişti. Zehirlenmelerin \%77,2'si ilaçlarla meydana gelmişti ve \%18,3'ü çoğul ilaç alımına bağlıydı. En sık gözlenen ilaç grubu \%24,2 ile santral sinir sistemi ilaçlarıydı. İlaç dışı zehirlenme nedenlerinde en sık görülen etkenin \%42,8 ile pestisit ve insektisitler olduğu görüldü. Zehirlenme sonrası acil servise başvuru süresi ortanca 60 (10-2880) dakikaydı. Olguların \%31,5'i bulguya yönelikti. Olguların \%65,2'sine mide yıkama işlemi, \%72,8'ine ise oral aktif kömür uygulandı. Toplam 3 olguya sürekli venövenöz hemodiyafiltrasyon yapıldı.

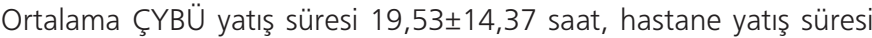
ise $35,91 \pm 29,46$ saatti. Çalışma süresinde özkıyım amaçlı alfa lipoik asit zehirlenmesi olan bir olgu kaybedildi.

Sonuç: Çocukluk çağı zehirlenmeleri acil servis başvurularının ve hastane yatışlarının önde gelen nedenlerinden olup, morbidite ve mortalitenin önlenebilir bir nedenidir. Zehirlenmelerin büyük çoğunluğu evde bulunan ilaçlar ve temizlik ürünleriyle gerçekleştiğinden, ailelerin zehirlenmeler konusunda bilgilendirilmesi ve ilaçlar ile temizlik ürünlerinin çocukların erişemeyeceği yerlerde saklanması önemlidir. Ayrıca çocukluk çağı zehirlenmelerinin epidemiyolojik ve klinik özelliklerinin sağlık çalışanları tarafından bilinmesi hızlı tanı ve tedavi açısından büyük önem taşır.

Anahtar Kelimeler: Zehirlenme, çocuk yoğun bakım ünitesi, epidemiyoloji, ilaç alımı, özkıyım

\section{Abstract}

Introduction: The aim of this study was to investigate demographic, epidemiologic, and clinical characteristics of cases admitted to pediatric intensive care unit (PICU) for poisoning.

Methods: Cases with poisoning admitted to PICU between January 1, 2015 and June 30, 2016 were evaluated retrospectively.

Results: Ninety two cases were enrolled in this study. The mean age was $63.65 \pm 59.1$ months and $73.9 \%$ of the cases were under 5 years of age. Fifty five point four percent of the cases were male. Of the poisoning cases, $82.6 \%$ were accidental and $14.1 \%$ were suicidal. Seventy seven point two percent of the cases were drug related and $18.3 \%$ of them were multi-drug poisonings. Central nervous system drugs were the most frequently (24.2\%) ingested drugs. The most common cause of non-drug poisonings were pesticide and insecticides (42.8\%). The median duration of time from ingestion to admission to the pediatric emergency department was 60 (10-2880) minutes. Of the cases, $31.5 \%$ were symptomatic. Gastric lavage and activated charcoal were performed in $65.2 \%$ and $72.8 \%$ of the cases, respectively. Continuous venovenous hemodiafiltration was performed in 3 cases. The mean time of PICU and hospital stay were $19.53 \pm 14.37$ and $35.91 \pm 29.46$ hours, respectively. During the study period, one case died due to acute poisoning of alpha-lipoic acid.

Conclusion: Pediatric poisonings are among the most common reasons for referrals to emergency department, admission to hospital and represent a preventable cause of morbidity and mortality. Parental education about prevention of poisoning and keeping drugs and household products out of children's reach is important because most of the poisonings occur at home with drugs and household products. Recognition of epidemiologic and clinical characteristics of pediatric poisoning by healthcare providers is also important for rapid diagnosis and treatment.

Keywords: Poisoning, pediatric intensive care unit, epidemiology, drug ingestion, suicide

Yazışma Adresi/Address for Correspondence: Dr. Çağlar Ödek, Diyarbakır Çocuk Hastalıkları Hastanesi, Çocuk Yoğun Bakım Ünitesi, Diyarbakır, Türkiye E-posta: caglar_odek@hotmail.com ORCID ID: orcid.org/0000-0002-2521-3411 Geliş Tarihi/Received: 19.12.2018 Kabul Tarihi/Accepted: 04.02.2019 


\section{Giriş}

Zehirlenmeler çocukluk çağı morbidite ve mortalitesinin sık görülen ve önlenebilir nedenlerinden olup, gelişmiş ülkeler de dahil olmak üzere tüm dünyada çocuk acil servislerine başvuru ve hastane yatışlarının önde gelen nedenlerindendir. ${ }^{1}$ Amerika Birleşik Devletleri'nde 2016 yilında meydana gelen 2,16 milyon zehirlenmenin \%60,3'ü 19 yaş ve altında, \%46,6'sı ise 5 yaş ve altındaki çocuklarda gerçekleşmiştir. ${ }^{2}$ Ulusal Zehir Danışma Merkezi'nin (UZEM) çalışma raporuna göre ülkemizde 2008 yllında yapılan 77,988 başvurunun 46,894'ü $(\% 60,1) 19$ yaş ve altındaki olgular için yapıımış olup, bunların da \%52,8'ini 5 yaş altı çocuklar oluşturmaktadır. ${ }^{3}$ Zehirlenme olgularının tanı ve tedavileri çoğunlukla çocuk acil servislerinde yürütülmekle birlikte, bazı olgularda çocuk yoğun bakım ünitesinde (ÇYBÜ) takip ve tedavi gerekebilir. ${ }^{4}$

Çocukluk çağı zehirlenmelerinin epidemiyolojisi ülkeden ülkeye, aynı ülke içinde bölgeden bölgeye, sosyo-kültürel yapıya, ekonomik düzeye ve yaşa göre değişkenlik gösterir. ${ }^{5}$ illaçlar, pestisitler, temizlik ürünleri, zehirli bitkiler, zehirli hayvan ısırma ve sokmaları, bağımlılık yapııı maddeler ülkemizde ve dünyada en sık görülen zehirlenme nedenleridir. ${ }^{6}$ Zehirlenme kaza sonucu ya da özkıyım amaçlı gerçekleşebilir, asemptomatik olabileceği gibi ciddi morbidite ve mortalite ile seyredebilir. ${ }^{4} \mathrm{Bu}$ nedenle her ülkenin ve bölgenin kendi zehirlenme olgularını içerecek epidemiyolojik çalışmalar yapması, sonuçlarına göre önleyici girişimlerde bulunması, uygun tanı ve tedavi hizmetlerinin sağlanması büyük önem taşımaktadır. ${ }^{5}$

Bu çalışmanın amacı hastanemiz çYBÜ'ye yatarak tedavi gören zehirlenme olgularının demografik, epidemiyolojik ve klinik özellikleri ile prognozlarını geriye yönelik olarak tespit etmek ve ülkemiz çocukluk çağı zehirlenme verilerine katkı sağlamaktır.

\section{Gereç ve Yöntem}

Hastanemiz 13 adet 3. basamak ve 24 adet 2. basamak (12'si ara yoğun bakım ünitesi) olmak üzere toplam 37 yoğun bakım yatağı ile hizmet veren bir devlet hastanesidir. Ünitede mesai saatleri içerisinde 1 çocuk yoğun bakım uzmanı, 3 çocuk sağ ığı ve hastalıkları uzmanı ve 14 hemşire, mesai sonrası saatlerde ise 1 çocuk sağlığı ve hastalıkları uzmanı ile 11 hemşire görev yapmaktadır. Ünitemize dahili, cerrahi (kardiyovasküler cerrahi hastaları hariç) ve travma hastaları kabul edilmekte olup takip edilen hasta sayısı yılda yaklaşık 2500 civarındadır. Hastanemiz ÇYBÜ'ye 1 Ocak 2015-30 Haziran 2016 tarihleri arasında zehirlenme tanısıly yatıılarak takip ve tedavileri yapılan 1 ay-18 yaş aralığındaki olgular geriye dönük olarak incelendi. Çocuk acil servisimizde ilk değerlendirme ve müdahaleleri yapılan olgulardan toksik dozda ilaç alanlar, zehirlenme bulguları olanlar ve UZEM'in yoğun bakım koşullarında izlenmesini önerdikleri ÇYBÜ'sine yatırıldı. Olguların dosyaları yaş, cinsiyet, zehirlenmeye neden olan madde ve karşılaşma yolu, zehirlenmenin şekli, zehirlenmenin nerede gerçekleştiği, zehirlenme ile çocuk acil servis başvurusu arasında geçen süre, başvuru anında bulgu varlığı, uygulanan tedaviler, ÇYBÜ ve hastane yatış süreleri ile zehirlenmenin sonucuna ait veriler açısından tarandı. Dosya verilerine ulaşılamayan, servise yatırılarak gözlenen veya ÇYBÜ'de boş yatak olmamasından dolayı diğer sağlık kuruluşlarına sevk edilen olgular ile besin zehirlenmeleri çalışmaya dahil edilmedi.

Zehirlenme nedenleri ilaç ve ilaç dışı nedenler olmak üzere iki gruba ayrıldı. Illaç dışı nedenler pestisit ve insektisitler, temizlik ürünleri ve koroziv maddeler, alkol ve diğer bağımlılık yapıcı maddeler, zehirli hayvan ısırması veya sokması olarak sınıflandırıldı.

Uygulanan tedaviler ise mide yıkama işlemi, oral aktif kömür, antidot kullanımı, ekstrakorporeal tedaviler (hemodiyaliz, hemofiltrasyon, plazmaferez ve terapötik plazma değişimi) ve destek tedavi olmak üzere gruplandı.

Bu çalışma için TC Sağılık Bilimleri Üniversitesi Diyarbakır Gazi Yaşargil Eğitim ve Araştırma Hastanesi Klinik Araştırmalar Etik Kurulu'ndan onay alındı (2017/95).

\section{Istatistiksel Analiz}

Verilerin istatistiksel analizinde SPSS 15.0 (Statistical Package For Social Sciences for Windows v. 15.0 SPSS Inc.; Chicago, IL, USA) programı kullanıldı. Tanımlayıcı istatistik olarak sürekli değişkenler ortalama \pm standart sapma ve ortanca (minimummaksimum), kategorik değişkenler ise sayı ve yüzde değer (\%) biçiminde gösterildi.

\section{Bulgular}

Çalışma süresinde ÇYBÜ'de toplam 98 zehirlenme olgusu yatıııldı. Altısının dosya verileri eksik olduğundan 92 olgu çalışmaya dahil edildi. Ortalama yaş $63,65 \pm 59,1$ aydı. Yaş gruplarına göre ayrıldıklarında olguların $\% 73,9^{\prime} u<5$ yaş, $\% 7,6$ 'sı 5-12 yaş ve $\% 18,5^{\prime} \mathrm{i} 12-18$ yaş aralığındaydı. Olguların 41'i $(\% 44,6)$ kız, 51'i $(\% 55,4)$ erkekti.

Zehirlenmeler, olguların 76'sında $(\% 82,6)$ kaza sonucu, 13 'ünde $(\% 14,1)$ özkıyım amaçlı meydana gelmişti. illk 5 yaş ve 5-12 yaş gruplarında zehirlenmelerin tamamı kaza sonucu gerçekleşirken, 12-18 yaş grubunda bu oran \%5,9 olarak saptandı. Özkıyım ve madde kullanımı nedenleriyle gerçekleşen zehirlenmelerde ortalama yaş $179,62 \pm 11,70$ ay, kaza sonucu gerçekleşen zehirlenmelerde ise $39,28 \pm 27,23$ ay olarak bulundu. Olguların demografik özellikleri ve zehirlenme şekilleri Tablo 1'de gösterilmiş̧ir.

Zehirlenmelere $71(\% 77,2)$ olguda ilaçların neden olduğu görüldü. Bu zehirlenmelerin \%18,3'ü çoğul ilaç alımına bağlıydı 
ve 71 olguda toplam 91 ilaç ile zehirlenme meydana gelmişti. Zehirlenmeye en sık neden olan ilaç grubu santral sinir sistemi ilaçları $(\% 24,2)$ ve bunların içerisinde de antiepileptik ilaçlardı (\%50). Illaçlar tek tek değerlendirildiğinde ise parasetamol $\% 12,1$ ile zehirlenmeye en sık neden olan maddeydi. Ilaç dışı zehirlenme nedenlerine bakıldığında ise 21 olgunun 9'unda $(\% 42,8)$ pestisit ve insektisitlerin etken olduğu saptandı. Zehirlenmeye neden olan maddeler Tablo 2'de ayrıntılarıla gösterilmiştir. Zehirlenmeler \%91,3 ağız yoluyla, \%6,5 deri yoluyla ve \%2,2 oranında inhaler yoldan meydana gelmişti. Seksen iki $(\% 89,1)$ olguda zehirlenme ev ortamında, 10 $(\% 10,9)$ olguda ise dış ortamda gerçekleşmişti.

Zehirli maddeye maruziyet sonrasında acil servise başvuru süresi

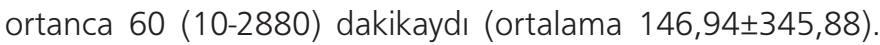
Özkıyım amacıyla gerçekleşen zehirlenmelerde ise bu süre

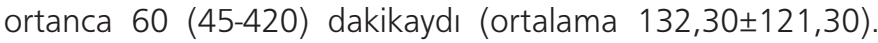
Çocuk acil servis başvurusunda olguların \%31,5'inde zehirlenmeye bağlı bulgular mevcut olup, bulguya yönelik olguların \%20,6'sında birden fazla organ sistemine ait bulgular görüldü. Olguların \%9,8'i ÇYBÜ'ye, \%90,2'si ise ara yoğun bakım ünitesine yatııılı. Zehirlenmelere bağlı bulgular Tablo 3'te verilmiştir.

Toksik maddelerin emilimini engellemek amacıyla $60(\% 65,2)$ olguda mide yıkama işlemi, $67(\% 72,8)$ olguda ise oral aktif kömür uygulaması yapıldı. Parasetamol zehirlenmesi olan 11 olguya damar içi $\mathrm{N}$-asetil sistein, tirotoksikozda olan 2 olguya propiltiourasil, kolestiramin ve propranalol, yılan ısırması olan 2 olguya da antivenom uygulandı. Karbamezapin zehirlenmesi olan iki olguya toksik maddenin vücuttan uzaklaştırılması, alfa lipoik asit zehirlenmesi olan bir olguya ise ağır metabolik ve laktik asidozun düzeltilmesi amacıyla sürekli venövenöz hemodiyafiltrasyon (SVVHDF) uygulandı. Diğer olgularda ise gözlem ve destek tedavi uygulandı.

Ortalama ÇYBÜ yatış süresi $19,53 \pm 14,37$ saat, hastane yatış süresi ise $35,91 \pm 29,46$ saat olarak bulundu. Çalışma süresinde özkıyım amaçlı yüksek doz alfa lipoik asit alımı olan $1(\% 1,1)$ olgu kaybedilirken, 91 olgu şifa ile taburcu edildi.

\section{Tartışma}

Zehirlenmeler çocukluk çağının önemli bir sağlık sorunudur ve çoğunlukla 5 yaş ve altında gerçekleşir. ${ }^{7}$ Nedeni ise bu yaşlarda çocukların meraklı olmaları ve dış dünyayı tat duyusu da dahil olmak üzere tüm duyuları ile tanımaya çalışmalarıdır. ${ }^{8}$ Ülkemizde yapılan farklı çalışmaların sonuçları incelendiğinde çocukluk çağı zehirlenmelerinin \%43,5 ila \%73,8'inin 5 yaş ve altında gerçekleştiği görülmektedir. ${ }^{711}$ Bizim çalışmamızda da benzer şekilde olguların \%73,9'u 5 yaş ve altındaydı. Cinsiyet dağılımına bakıldığında zehirlenmelerin 5 yaş ve altında daha çok erkeklerde, 12 yaş ve üzerinde ise kızlarda gerçekleştiği gösterilmiştir. ${ }^{9-11}$ Bizim çalışmamızda da benzer şekilde zehirlenmeler $<5$ ve 5-12 yaş gruplarında erkeklerde (sırasıyla $\% 60,3$ ve \%71,4), 12-18 yaş grubunda ise kızlarda $(\% 70,6)$ daha fazla görülmekteydi.

Zehirlenmeler kaza sonucu ya da özkıyım amacıyla gerçekleşebilir. Ülkemizde yapılan farklı çalışmalarda kaza sonucu meydana gelen zehirlenmeler \%53,7 ila \%90, özkıyım amaçlı zehirlenmeler ise \%8,2-46,3 aralığında saptanmıştır. ${ }^{6-10}$ Kaza sonucu meydana gelen zehirlenmeler çoğunlukla 5 yaş ve altında gerçekleşirken ${ }^{4}$, özkııım amaçı zehirlenmeler ise ergen yaş grubunda daha sık görülmektedir. ${ }^{5}$ Bizim çalışmamızda zehirlenmelerin \%82,6'sının kaza sonucu, \%14,1'inin özkıyım amacıyla, \%3,3'ünün ise madde kullanımı nedeniyle gerçekleştiği saptandı. Kaza sonucu gerçekleşen zehirlenme oranının önceki çalışmalara göre yüksek oluşu, çalışmamızda 5 yaş ve altındaki olguların sayısının da yüksek olmasıyla ilişkilendirildi. Önceki çalışmalar kaza sonucu gerçekleşen zehirlenmelerin erkeklerde ${ }^{5}$, özkııım amaçlı zehirlenmelerin ise ergen kızlarda daha sık görüldüğünü bildirmektedir. ${ }^{12}$ Bizim verilerimiz de bu çalışmalar ile benzer olup kaza sonucu gerçekleşen zehirlenmeler erkeklerde $(\% 60,5)$, özkıyım amaçlı zehirlenmeler ise kızlarda $(\% 76,9)$ daha sık gerçekleşmişti.

Andiran ve Sarıkayalar ${ }^{13}$ çocuklarda zehirlenmelerin en sık ağız yoluyla ve ev ortamında gerçekleştiğini bildirmişlerdir. Başka bir çalışmada Akın ve ark. ${ }^{10}$ zehirlenmelerin \%96,1 oranında ağız yoluyla ve \%96,1 oranında evde gerçekleştiğini göstermişlerdir. Benzer şekilde bizim çalışmamızda da

Tablo 1. Olguların demografik özellikleri ve zehirlenme şekilleri

\begin{tabular}{|c|c|c|c|c|c|c|c|c|}
\hline \multirow{2}{*}{$\begin{array}{l}\text { Yaş grupları } \\
\text { Cinsiyet }\end{array}$} & \multicolumn{2}{|c|}{$\begin{array}{l}<5 \text { yaş } 68(\% 73,9) \\
\text { n }(\%)\end{array}$} & \multicolumn{2}{|c|}{$\begin{array}{l}5-12 \text { yaş } 7(\% 7,6) \\
\text { n }(\%)\end{array}$} & \multicolumn{2}{|c|}{$\begin{array}{l}12-18 \text { yaş } 17(\% 18,5) \\
\text { n }(\%)\end{array}$} & \multicolumn{2}{|c|}{$\begin{array}{l}\text { Toplam } 92(\% 100) \\
\text { n (\%) }\end{array}$} \\
\hline & E & K & E & $\mathrm{K}$ & E & K & $\mathbf{E}$ & $\mathrm{K}$ \\
\hline Kaza sonucu & $\begin{array}{l}41 \\
(\% 44,6)\end{array}$ & $\begin{array}{l}27 \\
(\% 29,3)\end{array}$ & $\begin{array}{l}5 \\
(\% 5,4)\end{array}$ & $\begin{array}{l}2 \\
(\% 2,2)\end{array}$ & $\begin{array}{l}0 \\
(\% 0,0)\end{array}$ & $\begin{array}{l}1 \\
(\% 1,1)\end{array}$ & $\begin{array}{l}46 \\
(\% 50)\end{array}$ & $\begin{array}{l}30 \\
(\% 32,6)\end{array}$ \\
\hline Özkıyım & $\begin{array}{l}0 \\
(\% 0,0)\end{array}$ & $\begin{array}{l}0 \\
(\% 0,0)\end{array}$ & $\begin{array}{l}0 \\
(\% 0,0)\end{array}$ & $\begin{array}{l}0 \\
(\% 0,0)\end{array}$ & $\begin{array}{l}3 \\
(\% 3,3)\end{array}$ & $\begin{array}{l}10 \\
(\% 10,9)\end{array}$ & $\begin{array}{l}3 \\
(\% 3,3)\end{array}$ & $\begin{array}{l}10 \\
(\% 10,9)\end{array}$ \\
\hline Madde kullanımı & $\begin{array}{l}0 \\
(\% 0,0)\end{array}$ & $\begin{array}{l}0 \\
(\% 0,0)\end{array}$ & $\begin{array}{l}0 \\
(\% 0,0)\end{array}$ & $\begin{array}{l}0 \\
(\% 0,0)\end{array}$ & $\begin{array}{l}2 \\
(\% 2,2)\end{array}$ & $\begin{array}{l}1 \\
(\% 1,1)\end{array}$ & $\begin{array}{l}2 \\
(\% 2,2)\end{array}$ & $\begin{array}{l}1 \\
(\% 1,1)\end{array}$ \\
\hline Toplam & $\begin{array}{l}41 \\
(\% 44,6)\end{array}$ & $\begin{array}{l}27 \\
(\% 29,3)\end{array}$ & $\begin{array}{l}5 \\
(\% 5,4)\end{array}$ & $\begin{array}{l}2 \\
(\% 2,2)\end{array}$ & $\begin{array}{l}5 \\
(\% 5,5)\end{array}$ & $\begin{array}{l}12 \\
(\% 13,1)\end{array}$ & $\begin{array}{l}51 \\
(\% 55,4)\end{array}$ & $\begin{array}{l}41 \\
(\% 44,6)\end{array}$ \\
\hline
\end{tabular}


Tablo 2. Zehirlenmeye neden olan maddeler

\begin{tabular}{|c|c|}
\hline Zehirlenmeye neden olan maddeler & n (\%) \\
\hline A. İlaçlar & $91(\% 100)$ \\
\hline Santral sinir sistemi ilaçları & $22(\% 24,2)$ \\
\hline Trisiklik antidepresanlar & $2(\% 2,2)$ \\
\hline SSRI & $3(\% 3,3)$ \\
\hline Antipsikotikler & $3(\% 3,3)$ \\
\hline Psikostimülanlar & $1(\% 1,1)$ \\
\hline Antiparkinson & $2(\% 2,2)$ \\
\hline Karbamezapin & $4(\% 4,4)$ \\
\hline Lamotrijin & $2(\% 2,2)$ \\
\hline Valproik asit & $2(\% 2,2)$ \\
\hline Fenitoin & $2(\% 2,2)$ \\
\hline Klonazepam & $1(\% 1,1)$ \\
\hline Analjezik ve antipiretikler & $19(\% 20,9)$ \\
\hline Parasetamol & $11(\% 12,1)$ \\
\hline Salisilik asit & $6(\% 6,6)$ \\
\hline Metamizol & $2(\% 2,2)$ \\
\hline Kardiyovasküler sistem ilaçları & $14(\% 15,4)$ \\
\hline Diüretikler & $2(\% 2,2)$ \\
\hline Beta blokörler & $1(\% 1,1)$ \\
\hline ACE inhibitörleri & $3(\% 3,3)$ \\
\hline Anjiyotensin II reseptör antagonistleri & $2(\% 2,2)$ \\
\hline Kalsiyum kanal blokörleri & $3(\% 3,3)$ \\
\hline Kardiyak glikozidler & $1(\% 1,1)$ \\
\hline Antiiskemik ilaçlar & $1(\% 1,1)$ \\
\hline Alfa blokörler & $1(\% 1,1)$ \\
\hline Diğer ilaçlar & $36(\% 39,5)$ \\
\hline Antibiyotik grubu & $4(\% 4,4)$ \\
\hline Hormon preparatları (tiroksin) & $4(\% 4,4)$ \\
\hline Demir preparatları & $5(\% 5,5)$ \\
\hline Kolşisin & $2(\% 2,2)$ \\
\hline Kas gevşetici ve spazmolitikler & $5(\% 5,5)$ \\
\hline Bronkodilatatörler & $3(\% 3,3)$ \\
\hline Antihistaminikler & $2(\% 2,2)$ \\
\hline Vitaminler & $2(\% 2,2)$ \\
\hline Gis ilaçları & $3(\% 3,3)$ \\
\hline Antikoagülanlar & $2(\% 2,2)$ \\
\hline Alfa lipoik asit & $1(\% 1,1)$ \\
\hline İzotretinoin & $1(\% 1,1)$ \\
\hline Nikotin & $1(\% 1,1)$ \\
\hline Metotreksat & $1(\% 1,1)$ \\
\hline B. İlaç dışı maddeler & $21(\% 100)$ \\
\hline Pestisit ve insektisitler & $9(\% 42,8)$ \\
\hline Koroziv maddeler ve diğer temizlik ürünleri & $4(\% 19)$ \\
\hline Petrol türevleri & $1(\% 4,8)$ \\
\hline Yılan ısırmaları & $4(\% 19)$ \\
\hline Esrar & $1(\% 4,8)$ \\
\hline Alkol & $1(\% 4,8)$ \\
\hline Endüstriyel yapıştırıcı & $1(\% 4,8)$ \\
\hline
\end{tabular}

zehirlenmelerin \%91,3'ünün ağız yoluyla gerçekleştiği ve tüm zehirlenme olgularının \%89,1'inin evde meydana geldiği saptandı. Bunun nedeni ise çalışma grubumuzdaki zehirlenmelerin büyük bölümünün evlerde bulunan ve ağız yoluyla alınan ilaçlar nedeniyle gelişmesi olarak değerlendirildi. Çocukluk çağı zehirlenmelerinin çoğunluğu ilaçlar ile meydana gelmektedir. Illaçlarla zehirlenme oranları Gauvin ve ark. ${ }^{14}$ tarafından \%80, Akın ve ark. ${ }^{10}$ tarafından $\% 76,1$, Güngörer ve ark. ${ }^{6}$ tarafından ise $\% 78,04$ olarak bildirilmektedir. Bizim çalışamamızda da benzer şekilde zehirlenmelerin \%77,2 oranında ilaçlarla meydana geldiği saptanmıştır. Akgül ve ark. ${ }^{9}$ ilaçlarla olan zehirlenmelerin $\% 84,7$ oranında tek ilaçla gerçekleştiğini göstermişlerdir. Bizim çalışmamızda bu oran \%81,7 olarak bulunmuştur. Tekerek ve ark. ${ }^{7}$ özkıyım amacıyla gerçekleşen zehirlenmelerde çoğul ilaç kullanımının daha yüksek oranda görüldüğünü bildirmişlerdir ancak bizim çalışmamızda özkıyımların \%69,2 oranında yine tek ilaç veya madde alımı ile gerçekleştiği görülmüştür.

Zehirlenmelere neden olan ilaç grupları ülkelere, ülkeler içindeki coğrafi bölgelere, sosyo-ekonomik koşullara ve kültürel farklılıklara göre değişkenlik gösterir. Yurtdışında yapılan çalışmalarda öncelik sırası değişmekle birlikte analjeziklerin ve santral sinir sistemi ilaçlarının zehirlenmeye en sık yol açan ilaçlar oldukları saptanmıştır. ${ }^{13-16}$ Ülkemizde yapılan çalışmalarda da benzer sonuçlara ulaşıımış ve analjezik-antipiretikler ile santral sinir sistemi ilaçlarının zehirlenmelere en sık neden olan ilaçlar olduğu gözlenmiştir. ${ }^{79,12}$ Bu durum ülkemizde analjezikantipiretikler ile antidepresanların reçetesiz temin edilebilmesi ve yaygın kullanılmalarına bağlanmaktadır. ${ }^{8}$ Çalışmamızda da

\section{Tablo 3. Zehirlenmeye ait bulgular}

\begin{tabular}{ll|}
\hline Bulgular & $\mathbf{n}(\%)^{*}$ \\
\hline Gastrointestinal & $\mathbf{1 5}(\% \mathbf{5 1 , 7 )}$ \\
\hline Bulantı & $7(\% 24,1)$ \\
\hline Kusma & $9(\% 31)$ \\
\hline Karın ağrısı & $7(\% 24,1)$ \\
\hline Diyare & $1(\% 3,4)$ \\
\hline Nörolojik & $\mathbf{1 0}(\% 34,4)$ \\
\hline Bilinç bozukluğu & $5(\% 17,2)$ \\
\hline Uykuya meyil & $2(\% 6,8)$ \\
\hline Konvülziyon & $2(\% 6,8)$ \\
\hline Kardiyovasküler & $\mathbf{4 ( \% 1 3 , 7 )}$ \\
\hline Taşikardi & $2(\% 6,8)$ \\
\hline Hipotansiyon & $1(\% 3,4)$ \\
Solunum & $\mathbf{3}(\% 10,3)$ \\
\hline Takipne & $2(\% 6,8)$ \\
\hline Deri & $\mathbf{4 ( \% 1 3 , 7 )}$ \\
\hline Eritem ve ödem & $4(\% 13,7)$ \\
*Bulguya yönelik olan 29 olgunun altısında birden fazla sisteme ait bulgular \\
mevcuttu
\end{tabular}


zehirlenmelere en çok neden olan ilaç grupları santral sinir sistemi ilaçları ile analjezik ve antipiretikler olarak bulunmuştur. Bunları ise kardiyovasküler sistem ilaçları takip etmektedir.

ilaç dışı maddelerle zehirlenmeler de tıpkı ilaçla zehirlenmeler gibi coğrafi bölgelere, yerleşim yerlerine, sosyo-ekonomik koşullara ve mevsimlere göre değişkenlik gösterir. Kendirci ve ark. ${ }^{12}$ yaptıkları çalışmada olguların \%49'unda karbonmonoksit zehirlenmesi olduğu tespit etmiş, bunun nedeni olarak ta hastanenin hizmet verdiği bölgenin sosyoekonomik seviyesinin düşük olması ve evlerde kömür sobası kullanımının yaygın olması gösterilmiştir. Biçer ve ark. ${ }^{17}$ koroziv maddelerle zehirlenmelerde, yaz aylarında evlerde boya yapılma sıkığındaki artışın ve bu sırada kullanımı artan temizlik ürünlerinin etken olabileceğini öne sürmüşlerdir. Kızılyıldız ve ark. ${ }^{18}$ Van'da yaptıkları çalışmalarında ilaç dışı maddelerle gerçekleşen zehirlenmelere en sık pestisitlerin neden olduğunu saptamışlardır. Bizim çalışmamızda ilaç dışı maddelerle zehirlenmelerin oranı \%22,8 olarak bulunmuştur. ilaç dışı maddeler ise sıklık sırasına göre $\% 42,8$ pestisit ve insektisitler, \%23,8 temizlik ürünleri ve koroziv maddeler, $\% 19,1$ yılan ısırmaları ve \%14,3 bağımlıık yapıcı maddeler olarak sıralanmaktadır. Çalışmamızda pestisit ve insektisit zehirlenmeleri ile yılan ısırmalarının sıklığının fazla olması, bu olguların tarımla uğraşılan kırsal bölgelerde yaşamalarına bağlandı.

Zehirlenme sonrasında dekontaminasyon işlemlerinin yapılması ve uygun tedavinin başlanabilmesi için zehirlenme ile hastane başvurusu arasında geçen süre oldukça önemlidir. Çocuklarda kaza sonucu meydana gelen ilaç zehirlenmelerinde genellikle bulguların hafif olması nedeniyle bu sürenin çoğu olguda 2 saatten daha uzun sürdüğü bildirilmiştir. ${ }^{19}$ Ülkemizde doğu ve kuzey illerinde sağlık kuruluşuna başvuru süresinin batı ve güney illerine göre daha uzun olduğu saptanmış ve bu durum sosyo-ekonomik ve kültürel farklııklar ile arazi şartlarının ve ulaşımın kötü olmasıyla ilişkilendirilmiștir. ${ }^{20}$ Ülkemizden sırasıyla Samsun, Konya ve İstanbul'dan yapılan çalışmalarda acil servise başvuru süreleri ortalama 3,4 $\pm 3,03$ saat, 89,22 $\pm 94,37$ dakika ve $3,72 \pm 5,56$ saat olarak bildirilmiştir.6,8,10 Bizim çalışmamızda ise bu süre ortanca 60 (10-2880) dakika olarak saptanmıştır. Tekerek ve ark. ${ }^{7}$ çalışmasında özkıyım amacıyla meydana gelen zehirlenmelerde acil servise başvuru süresinin olguların $\% 58,7$ 'sinde 6 saatten daha uzun olduğu saptanmıştır. Bizim çalışmamızda ise bu süre ortalama $132,30 \pm 121,30$ dakika (ortanca 60;45-420) bulunmuştur. Sürenin kısa olmasının özkıyım girişiminde bulunan tüm olgularımızın ilaçları aldıktan kısa süre sonra ailelerine haber vermeleri ile ilişkili olduğunu düşünüyoruz.

Zehirlenme sonrası bulguya yönelik olma durumu zehirlenmeye neden olan maddeye, zehirli maddenin miktarına ve zehirlenme ile hastaneye başvuru arasında geçen süreye bağlı olarak değişebilmektedir. Acil servis başvurusunda bulguya yönelik olma yüzdesini Akgül ve ark. ${ }^{9} \% 28,7$, Akın ve ark. ${ }^{10}$ ise \%34,5 olarak bildirmişlerdir. Bizim çalışmamızda da benzer şekilde olguların \%31, $5^{\prime} i$ bulguya yönelikti. Literatür gözden geçirildiğinde zehirlenme olgularında en sık gastrointestinal sistem, ikinci sırada ise santral sinir sistemine ait bulguların gözlendiği saptandı. 8,9,12,21 Bizim çalışmamızda da sonuçlar benzerdi ve en sık gastrointestinal sistem $(\% 51,7)$ ardından da santral sinir sistemi $(\% 34,4)$ bulguları gözlendi.

Zehirlenme sonrası tanı ve tedavi basamakları genellikle hastanelerin çocuk acil servislerinde sürdürülür. Ancak kimi zehirlenmelerde olguların servise veya çYBÜ'ye yatırımaları gerekebilir. ${ }^{4}$ Çocuk acil servisine zehirlenme ile başvuran olguların hastaneye yatırıma oranları \%15,2$42,4^{5,9,20}$, ÇYBÜ'ye yatıııma oranları ise \%1,5-5,8 aralığında bildirilmiştir. ${ }^{9,10,20}$ Bizim çalışmamızda olguların 9'u $(\% 9,8)$ ÇYBÜ'ye, 83'ü $(\% 90,2)$ ise ara yoğun bakım ünitesine yatıııldı. Çalışma süresi içerisinde çocuk acil servisine başvuran toplam zehirlenme olgularının sayısı net olarak belirlenemediğinden, hastane ve ÇYBÜ'ye yatış oranları hesaplanamadı.

Zehirlenme sonrası uygulanacak tedaviler toksik maddenin gastrointesitnal sistemden emiliminin engellenmesi veya azaltılması, deri ve göz dekontaminasyonu, varsa antidotların kullanılması, toksik maddelerin metabolizmalarının değiştirilmesi, vücuttan atıımının hızlandırılması, ekstrakorporeal yöntemlerle detoksifikasyon ve destek tedavi olarak özetlenebilir.22,23 Çalışmamızda olguların \%65,2'sine mide yıkama işlemi yapılırken, \%72,8'ine oral aktif kömür uygulandı. Yorulmaz ve ark. ${ }^{8}$ ile Akgül ve ark.'nın ${ }^{9}$ yaptıkları çalışmalarda mide yıkama işleminin sırasıyla \%34,6 ve \%40, oral aktif kömürün ise sırasıyla $\% 42,7$ ve $\% 48$ oranlarında uygulandıkları saptanmışır. Bizim çalışmamızda bu uygulamaların daha yüksek oranda yapılmış olması zehirlenme sonrası acil servise başvuru süresinin ortanca 60 dakika gibi kısa olmasına bağlandı. Çocuk yoğun bakıma yatışı yapılan olgulardan $15^{\prime}$ ine $(\% 16,3)$ antidot ve antivenom uygulandı. Parasetamol zehirlenmelerinde plazma parasetamol düzeyi hastanemizde çalışılamadığından dolayı, toksik dozda alım olan tüm olgulara 20 saatlik $\mathrm{N}$-asetil sistein infüzyon protokolü ${ }^{24}$ uygulandı. Yılan ısırması olan 2 olguda ısırık yerinde ağır yerel yanıt oluştuğundan dolayı ilk 4 saat içerisinde antivenom uygulaması yapıldı. Üç $(\% 3,2)$ olguya sürekli venö venöz hemodiyafiltrasyon tedavisi uygulandı. Karbamezapin zehirlenmesi olan 2 olguda ÇYBÜ yatışları sırasında Glasgow Koma ölçeği $<8$ olup, konvülziyonları tespit edildiğinden SVVHDF ilk 1 saat içerisinde başlandı. Her iki olgunun da 4. saatte bilinci açıldı ve işlem 6 . saatte sonlandırıldı. Alfa lipoik asit zehirlenmesi olan bir olguya ise ağır metabolik ve laktik asidoz nedeniyle yatışın 1. saatinde SVVHDF başlandı ancak 
tedavilere yanıt alınamadı ve kaybedildi. Çalışmadaki diğer tüm olgulara destek tedavi verildi.

Yapılan çalışmalar zehirlenme olgularında ortalama ÇYBÜ yatış süresinin 1,2 ila 2,04 gün7,10,22, ortalama hastane yatış süresinin ise 20 saat ila 3,3 gün aralığında olduğunu göstermiştir.7,10,21

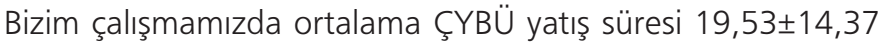
saat, toplam hastane yatış süresi ise $35,91 \pm 29,46$ saat bulundu ve bu sonuç önceki çalışmalar ile benzerdi. Literatür gözden geçirildiğinde ülkemizde zehirlenmelere bağlı mortalite oranının $\% 0$ ve 5,4 aralığında değiştiği görülmektedir. ${ }^{6-12}$ Bu çalısmada 92 olgudan $1(\% 1,1)$ tanesi kaybedilirken, diğer 91 olgu şifa ile taburcu edildi. Mortalite oranımı önceki çalışmalar ile uyumlu olarak bulundu.

\section{Çalışmanın Kısıtıııkları}

Bu çalışmanın geriye dönük dizaynı nedeniyle kısıtlı yönleri mevcuttur. En önemli kısıtlılık çalışma süresi içerisinde çocuk acil servisine başvuran zehirlenme olgularının gerçek sayısına ulaşılamamış olmasıdır. Sonuç olarak 18 aylık çalışma süresinde hastanemiz çocuk acil servisine başvuran toplam 270.749 hasta içerisinde zehirlenme olgularının yüzdesi ile hastane ve ÇYBÜ yatış oranları hesaplanamamıştır. Ayrıca çYBÜ'ye yatırılan 6 olgu dosya verileri eksik olduğundan çalışma dışı bırakılmıştır. Bu durum da örneklemin küçülmesine neden olmuştur.

\section{Sonuç}

Çocukluk çağı zehirlenmeleri acil servis başvurularının ve hastane yatışlarının önde gelen nedenlerinden olup, morbidite ve mortalitenin önlenebilir bir nedenidir. Çalışmamızda zehirlenmelerin \%77, 2'sinin ilaçlarla, \%9,7' sinin ise pestisit ve insektisitlerle kaza sonucu gerçekleştiği göz önüne alındığında ailelerin bilgilendirilmesi ve koruyucu önlemlerin alınmasının önemi bir kez daha ortaya çıkmaktadır. Buna ek olarak zehirlenmelerin epidemiyolojisinin bilinmesi, hızlı ve doğru tedavinin uygulanmasında büyük önem taşımaktadır. Zehirlenme sonucu hastaneye başvuran olgularda ÇYBÜ'ye yatış ve ileri düzey tedaviler gerekebildiğinden, ülke genelinde nitelikli çYBÜ'nün yaygınlaştırılması zehirlenmeye bağlı morbidite ve mortalitenin azaltılmasına büyük katkı sağlayacaktır.

\section{Etik}

Etik Kurul Onayı: Bu çalışma için T.C. Sağlık Bilimleri Üniversitesi Diyarbakır Gazi Yaşargil Eğitim ve Araştırma Hastanesi Klinik Araştırmalar Etik Kurulu'ndan onay alındı (2017/95).

Hasta Onayı: Çalışma dizaynı geriye dönük olduğundan etik kurul onayıyla hastaların bilgilendirilmiş gönüllü onamları alınmadı.
Hakem Değerlendirmesi: Editörler kurulu dışında olan kişiler tarafından değerlendirilmiştir.

\section{Yazarlık Katkıları}

Cerrahi ve Medikal Uygulama: Ç.Ö., H.A., M.E., R.D., M.T., A.A., F.F.T., S.S., Konsept: Ç.Ö., Dizayn: Ç.Ö., Veri Toplama veya işleme: M.E., R.D., M.T., A.A., F.F.T., S.S., Analiz veya Yorumlama: Ç.Ö., H.A., Literatür Arama: Ç.Ö., Yazan: Ç.Ö.

Çıkar Çatışması: Yazarlar tarafından çıkar çatışması bildirilmemiştir.

Finansal Destek: Yazarlar tarafından finansal destek almadıkları bildirilmiştir.

\section{Kaynaklar}

1. Nistor N1, Frasinariu OE1, Rugin A1, Ciomaga IM1, Jit reanu C2, Ştreang V1. Epidemiological study on accidental poisonings in children from northeast Romania. Medicine (Baltimore). 2018;97:e11469.

2. Gummin DD, Mowry JB, Spyker DA, Brooks DE, Fraser MO, Banner W. 2016 annual report of the American Association of Poison Control Centers' national poison data system (NPDS): 34th annual report. Clin Toxicol (Phila). 2017;55:1072-252.

3. Özcan N, ikincioğulları D. Ulusal zehir danışma merkezi 2008 yılı çalışma raporu özeti. Turk Hij Den Biyol Derg. 2009;66:ER:29-58.

4. Biçer $S$, Sezer $S$, Çetindağ $F$, Kesikminare $M$, Tombulca $N$, ve ark. Çocuk Acil Kliniği 2005 yılı akut zehirlenme olgularının değerlendirilmesi. Marmara Medical Journal. 2007;20:12-20.

5. Azab SM1, Hirshon Jm, Hayes Bd4, El-Setouhy M5,6, Smith Gs7, Sakr Ml1,8, Tawfik H8, Klein-Schwartz W9. Epidemiology of acute poisoning in children presenting to the poisoning treatment center at Ain Shams University in Cairo, Egypt, 2009-2013. Clin Toxicol (Phila). 2016;54:20-6.

6. Güngörer V1, Yisldırım NK1. Yeni Açılan İkinci Düzey Çocuk yoğun bakım birimimizde yatan zehirlenme olgularının değerlendirilmesi. Turk Pediatri Ars. 2016;51:35-9.

7. Tekerek NÜ, Dursun A, Akyıldız BN. Çocuk yoğun bakım ünitesinde takip edilen zehirlenme olgularının geriye dönük değerlendirilmesi. J Pediatr Emerg Intensive Care Med. 2016;3:21-6.

8. Yorulmaz A, Akbulut H, Yahya i, Aktaş R, Emiroğlu HH, ve ark. Çocuk acil servisine zehirlenme nedeni ile başvuran olguların geriye dönük olarak değerlendirilmesi. J Pediatr Emerg Intensive Care Med. 2017;4:96-103.

9. Akgül F, Er A, Çelik FÇ, Çağlar A, Ulusoy E, ve ark. Çocukluk çağ zehirlenmelerinin geriye dönük olarak incelenmesi. J Pediatr Emerg Intensive Care Med. 2016;3:91-6.

10. Akin Y1, Ağzikuru T, Cömert S, Atilkan P, Erdağ GC, Telatar B. Hospitalizations for pediatric intoxication: a study from İstanbul. Turk J Pediatr. 2011;53:369-74

11. Soyucen $E$, Aktan $Y$, Saral A, Akgün N, Numanoğlu AÜ. Sakarya bölgesinde çocukluk çağı zehirlenmelerinin geriye dönük değerlendirilmesi. Çocuk Sağlığı ve Hastalıkları Dergisi. 2006;49:301-6.

12. Kendirci HNP, Çolakoğlu EY, Hızlı ş, Koçak M, Saylam E, ve ark. Hastanemiz çocuk acil servisine başvuran zehirlenme olgularının değerlendirilmesi. Türkiye Çocuk Hast Derg. 2011;5:29-35. 
13. Andiran N1, Sarikayalar F. Pattern of acute poisonings in childhood in Ankara: what has changed in twenty years?. Turk J Pediatr. 2004;46:147-52.

14. Gauvin F1, Bailey B, Bratton SL. Hospitalizations for pediatric intoxication in Washington State, 1987-1997. Arch Pediatr Adolesc Med. 2001;155:1105-10.

15. Manzar N1, Saad SM, Manzar B, Fatima SS. The study of etiological and demographic characteristics of acute household accidental poisoning in children-a consecutive case series study from Pakistan. BMC Pediatr. 2010;3:10-28.

16. Lin YR1, Wu TK, Liu TA, Chou CC, Wu HP. Poison exposure and outcome of children admitted to a pediatric emergency department. World J Pediatr. 2011;7:143-9.

17. Biçer S, Yılmaz A, Keleş ES, Aydoğan G. Çocukluk çağı zehirlenmelerinde etiyolojik faktörlerin değerlendirilmesi. Turkiye Klinikleri J Pediatr. 2007;16:217-28.

18. Kizilyildiz BS1, Karaman K2, Özen S2, Üner A3. Acute intoxications among Turkish children. Minerva Pediatr. 2018;70:46-50.
19. Al Hazmi AM1. Patterns of accidental poisoning in children in Jeddah, Saudi Arabia. Ann Saudi Med. 1998;18:457-9.

20. Aji DY, illter Ö. Türkiye' de çocuk zehirlenmeleri. Türk Pediatri Ars. 1998;33:154-8.

21. Güzel IŞ, Kibar $A E$, Vidinlisan S. Çocuk acil servisine başvuran zehirlenme vakalarının demografik özelliklerinin incelenmesi. Genel Tip Derg. 2011;21:101-7.

22. Even KM1, Armsby CC, Bateman ST. Poisonings requiring admission to the pediatric intensive care unit: a 5-year review. Clin Toxicol (Phila). 2014;52:519-24

23. Kondolot M, Akyıldız B, Görözen F, Kurtoğlu S, Patıroğlu T. Çocuk acil servisine getirilen zehirlenme olgularının değerlendirilmesi. Çocuk Sağlığı ve Hastalıkları Dergisi. 2009;52:68-74.

24. Şevketoğlu E. Parasetamol Zehirlenmesi. Içinde: Çıtak A, Yılmaz HL (ed.ler). Pediatrik Zehirlenmeler. 1. Baskı. İstanbul, İstanbul Tıp Kitabevi, 2011:113-8. 